\title{
Assessment of bigh school teachers on their digital competences
}

Evaluación a profesores de secundaria sobre sus competencias digitales

Research Article | Artículo de investigación

Received on: November 11st, 2018 Accepted on: may 15th, 2019

Available online from: July 2020

doi: 10.11144/Javeriana.m13.ahst

SARA DiAs-TRINDADE sara.trindade@uc.pt

Universidade de Coimbra, Portugal ORCID: https://orcid.org/0000-0002-5927-3957

José António Moreira jmoreira@uab.pt

Universidade Aberta, Portugal ORCID: https://orcid.org/0000-0003-0147-0592

Para citar este artículo | To cite this article Dias-Trindade, S. \& Moreira, J. A. (2020). Assessment of high school teachers on their digital competences. magis, Revista Internacional de Investigación en Educación, 13, 1-21. doi: 10.11144/Javeriana.m13.ahst 


\section{Abstract}

Digital Technologies' potential has brought new challenges to teachers, making it essential to acquire digital competences that will allow them to effectively use those technologies. The aim of this research is to assess the Portuguese high school teachers' digital competence level. The quantitative methodology used emphasises the teachers' perception of their digital competences in three focal dimensions: teachers' professional and pedagogic competences and learners' competences. The findings show that teachers' digital competence level is moderate; the dimensions with the lowest values are "teachers' pedagogic competences" and "learners' competences". Subdimensions Assessment, Empowering Learners and Facilitating Learners' Digital Competence are the weakest.

\section{Keywords}

Digital technology; quantitative analysis; teacher training

\section{Resumen}

El potencial de las tecnologías digitales ha traído nuevos desafíos para los profesores, haciendo esencial el adquirir competencias digitales que les permitan usar efectivamente esas tecnologías. El propósito de esta investigación es evaluar el nivel de competencia digital de los profesores de portugués de secundaria. La metodología cuantitativa usada enfatiza la percepción de los profesores sobre sus competencias digitales en tres dimensiones focales: competencias profesional y pedagógica de los profesores y competencias de los aprendices. Los hallazgos muestran que el nivel de competencia digital de los profesores es moderado; las dimensiones con los valores más bajos son "competencias pedagógicas de los profesores" y "competencias de los aprendices". Las subdimensiones Evaluación, Empoderar a los aprendices y Facilitar la competencia digital de los aprendices son las más débiles.

\section{Palabras clave}

Tecnología digital; análisis cuantitativo; formación de docentes 
Descripción del artículo | Article description

Cientific text, derived from the project Avaliação das

Competências Digitais dos Professores em Portugal.

\section{Introduction}

The integration of digital technologies into the education system and, specifically, the development of digital learning ecosystems, enables the fulfilment of all the advantages associated with educational technologies, understood by different authors as motivating and promoters of diversified, hybrid, fertile and dynamic learning environments, which became increasingly complete (Miller \& Bartlett, 2012; White, 2013; McKnight, O'Malley, Ruzic, Horsley, Franey \& Bassett, 2016; Trindade \& Moreira, 2018). In this sense, the challenge is not only to integrate digital strategies in the classroom, but to use them in a way that allows the development of emancipatory skills, that is, to promote the development of a sense of belonging in their educational community and, later on, in their professional lives (Figueiredo, 2016).

The possibilities generated by technologies have completely changed the way people live, how people relate to knowledge and how it is achieved. In this context, it is increasingly difficult to distinguish between what is real and what is virtual, or what is human, machine or nature (Floridi, 2015). There is, therefore, a growing awareness that society is increasingly hybrid or, as suggested in The Onlife Manifesto (Floridi, 2015), with such fluidity between what is online and what is offline, that it no longer makes sense to separate one from another, leading its authors to opt with the term "onlife".

It is then necessary to rethink the way the school is perceived and how to define what should be the "best" pedagogy nowadays. Beetham \& Sharpe (2007) argue that learning is the central focus of pedagogy, and that it should be articulated with technology. Therefore, a school that focuses on learning is one that also makes a reflected, critical and thoughtful use of all the resources and all the strategies that digital technology allows. In this context, teachers have the central role in developing teaching strategies that provide students with active, collaborative and constructivist environments, promoting the development of skills appropriate to face the new Era and the new labour markets. 


\section{Problem of research}

Even though it is well known, for most people, that there is no longer a way to avoid letting technology into the school, many teachers either still try to avoid it or lack the abilities to make a meaningful use of it. Nevertheless, it is present in the daily routines of all students, making it an integral part of their lives. But, as Trindade \& Moreira (2017) state, the challenge lies in knowing how to use technology "to transform learning into a normal act of everyday life, making it so that's not even recognised as learning" (p. 55).

However, for this change to occur, both teachers and students must learn how to use digital technology in education in such a way that it truly creates innovative and sustainable scenarios, and where learning environments provide an effective improvement of the educational process. For this, teachers and students need to adapt to new times and learn to use digital technologies in an educational context (Ilomäki, Paavola, Lakkala \& Kantosalo, 2016; Pettersson, 2018). The everyday use of technology does not imply a natural conversion of its use at school. Also, in these new contexts, education can go beyond the physical space and time of a lesson. But, using technology to teach or learn and to extend learning to informal or non-formal environments requires specific skills in digital education (Carvalho \& Pessoa, 2012; European Commission, 2012; From, 2017; Generalitat de Catalunya, 2018; United Nations Educational, Scientific and Cultural Organization, 2011; The National Institute of Educational Technologies and Teacher Training, 2017; Van Laar, Van Deursen, Van Dijk \& Hann, 2017).

In addition, teaching and learning in this digital society is becoming an increasingly motivating yet demanding challenge, to which a training model, such as the theoretical framework of Technological Pedagogical Content Knowledge (TPACK) (Koehler \& Mishra, 2008; Mishra \& Koelher, 2006), which identifies the nature of the knowledge required for the integration of technology into teaching, can provide a very valid and effective response, since it points precisely to the interconnection between knowledge about the contents to be taught and the pedagogical knowledge. The aim of applying this reference to the teaching practice is that the teacher is able to make decisions based on the design of his or her teaching activities with technologies which, according to Cox (2008), presupposes: a) knowing how to use technologies, b) in a given curricular area, c) integrated in a pedagogical strategy, d) in a given educational context, e) to promote the construction of student knowledge (Trindade \& Moreira, 2017).

In fact, it is increasingly relevant to understand how to use digital technology positively and, above all, to know when and how its use produces a result that truly contributes to an improvement in the teaching and learning process. Therefore, if this same technology can support education and 
contribute to creating more efficient learning environments, then it is necessary to be digitally fluent (Ozan \& Kezim, 2013). As Schlemmer \& Backes (2015) state, "we are developing the ability to 'think with' and 'from' the use of these technologies, building virtual worlds that are also the worlds in which we live" (p. 305). In fact, digital technologies allows access to more knowledge, can provide more meaningful learning, allowing networking and much more collaborative work. All this combined can, in fact, provide more relevant learning.

However, there are hardly any studies that focus on the difference between knowing how to use digital technologies at school and actually being fluent at it. But at the end of the last century, more specifically in 1999, the US National Research Council was already pointing to the difference between someone who can work with technological tools, that is, someone who is digital or technologically literate, and someone who

understand[s] information technology broadly enough to be able to apply it productively at work and in their everyday lives, to recognize when information technology would assist or impede the achievement of a goal, and to continually adapt to the changes in and advancement of information technology (National Research Council, 1999, p. 15).

In the same text, three different types of knowledge are identified that characterise what its authors call FITness (fluency with information technology): Intellectual capacities to use the technologies in different complex and sustainable environments, and that fully articulate with the daily life of the citizen; concepts of the very basis from which information technologies are developed, which the authors argue are understood through practice and not merely by reading documents; skills always updated, in the sense that the user can use different technological tools and can adapt to their evolution and even to the emergence of new tools (National Research Council, 1999).

At this point, it is also important to know how to manage the enormous flow of information that can be accessed, knowing how to distinguish the essential from the accessory, or as Miller \& Bartlett (2012) refer, "to know how to tell the truth from the lies, and how to negotiate the grey areas of comment, opinion and propaganda in between" (p. 36).

\section{Research Focus}

Related to how teachers can interact with different digital tools, Wang, Myers \& Sundaram (2012) have demonstrated that the issue of digital fluency has nothing to do with ages or genres. They studied the difference 
between digital natives and immigrants, having prepared a model thereon which states that there are several factors to explain the digital fluency, namely the fact that

reciprocal relationship between actual use and digital fluency implies a potential virtuous circle to improve one's digital fluency. Alternatively, this could also imply a vicious circle, which deepens the digital divide (Wang et al., 2012, p. 10).

Research on the importance of digital fluency exists (Briggs \& Makice, 2012; Wang et al., 2012) but, until now, there are hardly any studies that focus on which dimensions of teachers' digital competences are strongest or weakest. This is important in order to be able to act upon it and find means to surpass the difficulties found in those specific dimensions.

Thus, which digital competences need to be further developed by Portuguese high school teachers? Providing and answer to this research question, through a questionnaire prepared by the EU Science Hub, and consequently assessing digital competence levels of Portuguese high school teachers is the aim of this research. Based on the findings, it should be possible to then design specific training, so that teachers feel confident about using digital technologies not only in collaboration with their peers, but especially with their students.

\section{Methodology of Research}

\section{General Background}

The research took place in two Portuguese high schools, one in Miranda do Corvo and another one in Sines, both with demographics that matched their geographical areas. The instrument used was one created by the EU Science Hub Department (Redecker \& Punie, 2017) and it is available online for public use. At each school the questionnaires were answered after teacher-training sessions, which were both held in May 2018.

\section{Sample of Research}

The sample was retrieved from two teacher-training sessions, organized by teacher-training centres. Teachers present at these sessions were asked to, anonymously, answer the instrument, which was done by 132 high school teachers.

Of the answers obtained, only 127 were analysed, since five questionnaires were not completely filled in. Among the 127 participants, 17 are 
male and 110 are female. No participant was less than 30 years of age and the age dispersion reflects the aging of the Portuguese teaching class, since only 18 teachers are between 30 and 39 years old (14,2\%), 54 are between the ages of 40 and 49 (42,5\%), 40 are between 50 and 59 years old $(31,5 \%)$ and 15 are over 60 years old $(11,8 \%)$.

As for the subjects taught, Maths and Experimental Sciences Department is the one with the most participants $(27,6 \%)$ and Social Sciences and Humanities Department is the one with the least (15\%) (table 1).

Table 1

Levels of education, departments and subjects of the participants

\begin{tabular}{|c|c|c|c|c|}
\hline \multirow{2}{*}{$\begin{array}{l}\text { Level of } \\
\text { Education }\end{array}$} & \multirow{2}{*}{ Department } & \multirow{2}{*}{ Level and subject } & \multicolumn{2}{|c|}{ Participants } \\
\hline & & & $\mathbf{N}$ & $\%$ \\
\hline $\begin{array}{l}\text { Primary } \\
\text { Education }\end{array}$ & $\begin{array}{l}\text { Primary } \\
\text { Education }\end{array}$ & Years 1 to 4 & 26 & 20,5 \\
\hline \multirow{19}{*}{$\begin{array}{l}\text { Lower and } \\
\text { Upper } \\
\text { Secondary } \\
\text { Education }\end{array}$} & \multirow{6}{*}{$\begin{array}{l}\text { Social Sciences } \\
\text { and Humanities } \\
\text { Department }\end{array}$} & $\begin{array}{l}\text { History and Geography of Portugal (Lower Secondary } \\
\text { Education) }\end{array}$ & \multirow{6}{*}{19} & \multirow{6}{*}{15,0} \\
\hline & & History (Lower and Upper Secondary Education) & & \\
\hline & & Geography (Lower and Upper Secondary Education) & & \\
\hline & & Philos & & \\
\hline & & Economics (Upper Secondary Education) & & \\
\hline & & Religion (Lower and Upper Secondary Education) & & \\
\hline & \multirow{6}{*}{ Arts Department } & Arts and Technology $\left(2^{\circ} \mathrm{CEB}\right)$ & \multirow{6}{*}{24} & \multirow{6}{*}{18,9} \\
\hline & & Music (Lower Secondary Education) & & \\
\hline & & $\begin{array}{l}\text { Physical Education (Lower and Upper Secondary } \\
\text { Education) }\end{array}$ & & \\
\hline & & Arts (Primary, Lower and Upper Secondary Education) & & \\
\hline & & Technology (Lower Secondary Education) & & \\
\hline & & $\begin{array}{l}\text { Special Needs Education (Lower and Upper Secondary } \\
\text { Education) }\end{array}$ & & \\
\hline & \multirow{3}{*}{$\begin{array}{l}\text { Languages } \\
\text { Department }\end{array}$} & Portuguese (Lower and Upper Secondary Education) & \multirow{3}{*}{23} & \multirow{3}{*}{18,1} \\
\hline & & English (Lower and Upper Secondary Education) & & \\
\hline & & French (Lower and Upper Secondary Education) & & \\
\hline & \multirow{4}{*}{$\begin{array}{l}\text { Math and } \\
\text { Experimental } \\
\text { Sciences } \\
\text { Department }\end{array}$} & $\begin{array}{l}\text { Maths and Nature Science (Lower Secondary } \\
\text { Education) }\end{array}$ & \multirow{4}{*}{35} & \multirow{4}{*}{27,6} \\
\hline & & Math (Lower and Upper Secondary Education) & & \\
\hline & & $\begin{array}{l}\text { Physics and Chemistry (Lower and Upper Secondary } \\
\text { Education) }\end{array}$ & & \\
\hline & & $\begin{array}{l}\text { Biology and Geology (Lower and Upper Secondary } \\
\text { Education) }\end{array}$ & & \\
\hline
\end{tabular}




\section{Instrument}

Identifying where high school teachers feel more confortable as well as where they struggle the most is, in fact, an increasingly important issue, because both national and internationally, there is a growing awareness that teachers must follow the digital evolution and qualify themselves for the use of digital technologies in educational environments. However, many teachers often feel that, on the one hand, the existing specialised training does not keep up with their real needs and, on the other hand, the school bureaucracy in which they are involved interferes with the time available to pursue education in this area.

These perceptions, however, result, for the most part, from loose opinions and superficial statements, and not so much from scientific studies as to how the majority of teachers are in terms of specific digital competences. And it is in this context that the EU Science Hub, a department of the European Union, has sought to identify the needs of educators at the level of digital competences, through the preparation of questionnaires, analysis and reports that support the work to be developed in this area. According to its website, research began in 2005 and focuses on finding a response so that DTICs will be used to "rethink [...] learning, for innovating education and training and for addressing new skills requirements (e. g., digital competence) to generate growth, employment and social inclusion" (EU Science Hub, 2019).

Among the different products that the EU Science Hub Department has been developing, DigCompEdu stands out, a report that presents a questionnaire with a common European framework for the digital skills of educators, launched in 2017, due to the awareness that teachers "need a set of digital competences specific to their profession in order to be able to seize the potential of digital technologies for enhancing and innovating education" (Redecker \& Punie, 2017, p. 8).

The European Department then developed an online questionnaire (DigCompEdu CheckIn), with the collaboration of several European countries, which can be answered by teachers of all levels of education, in order to identify the level of digital competence in which they find themselves. However, more than just listing a set of competences, this instrument provides users with a report that, based on the answers given, makes suggestions for improving the practices teachers already have. This is relevant as it allows the user to understand what he or she can do to move to the next level, following a logic of continuous learning that teachers are familiar with.

This questionnaire is currently being tested and will soon be available in different languages to teachers from all over Europe. In its online page, the authors indicate that 
this self-assessment tool is based on the European Framework for Digital Literacy Teachers, the European Digital Competence Framework for Educators (DigCompEdu). DigCompEdu is a competency model for teachers at all levels of education, from kindergarten to higher education and adult education, including VET, special education and non-formal learning contexts. DigCompEdu divides the digital competence teachers into 6 different areas [subdimensions] with a total of 22 competences. The focus of the model is not on technical skills. Rather, the model's claim is to capture how digital media can be used to enhance and modernize education and training (EUSurvey, n. d.).

Below are the three dimensions and six subdimensions addressed in the questionnaire, and their competences (figure 1).

Figure 1

Synthesis of the DigCompEdu framework

Educators' professional competences
Educators' pedagogic

competences
Learners' competences

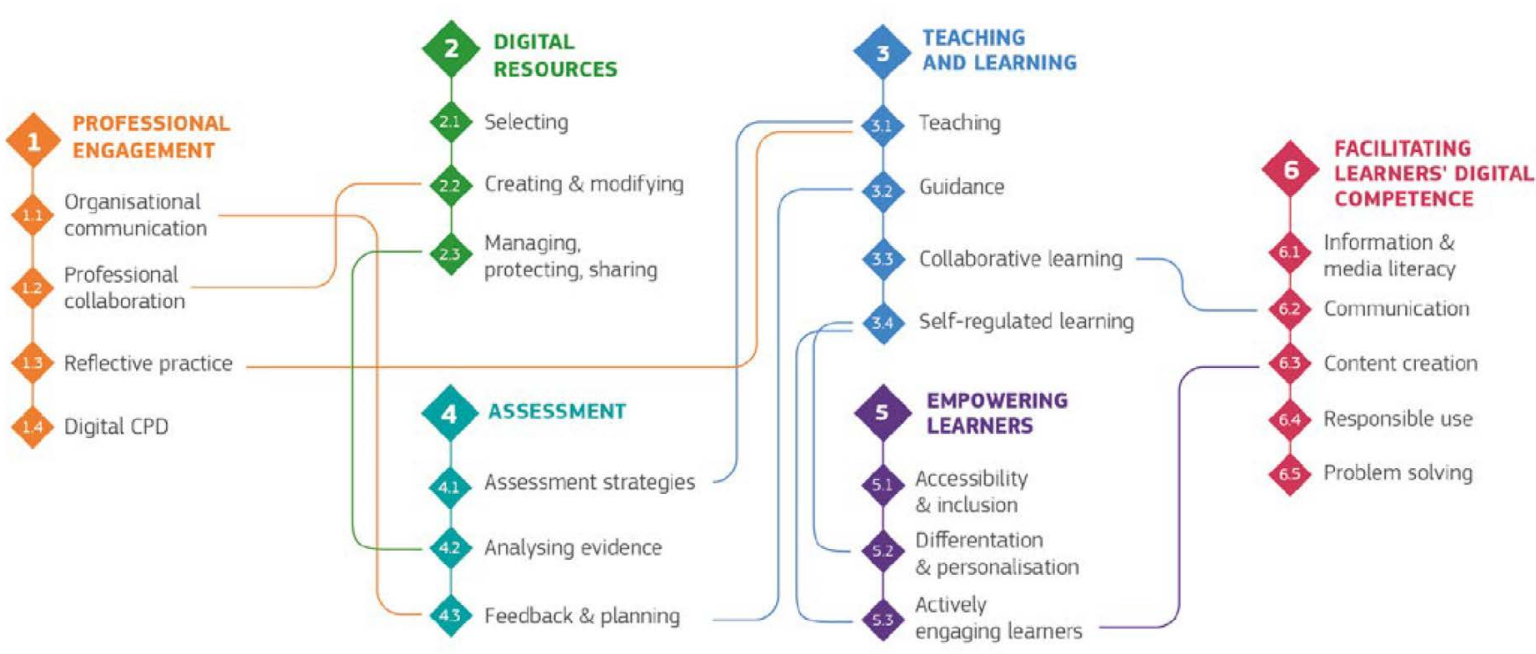

Source: Redecker \& Punie (2017, p. 8)

The first subdimension — Professional engagement - , framed in the first dimension -Educators' professional competences-, devotes its attention to professional development and seeks to make teachers aware of their competences regarding the use of digital technologies to communicate, collaborate and evolve professionally. 
The second subdimension —Digital resources - in turn, framed in the second dimension - Educators' pedagogic competences—, concerns digital resources and the ability to search, create, and share those resources.

The third subdimension - Teaching and learning —, also, framed in the second dimension, seeks to help teachers identify their ability to manage and organize the use of digital technologies in the teaching and learning process.

The fourth subdimension - Assessment-, still framed in the second dimension, is dedicated to assessment skills, in particular in the way digital technologies are used to improve the students' assessment process.

The fifth subdimension - Empowering learners - , the last one of the second dimension, focuses on the empowerment of students, including the ability to use digital technologies to increase inclusion, personalisation and active involvement of students in teaching.

Finally, the sixth subdimension -Facilitating learners' digital competence-, framed in the third dimension - Learners' competences - addresses teacher competences to assist students in the use of digital technologies and to gauge how teachers help their students to use digital technologies in a creative and responsible way.

In addition, it was possible to articulate the items presented in this tool for the recognition of digital competences, with another document, published in 2017 by the same working group, entitled The Digital Competence Framework for Citizens, which presents eight levels of digital competence and examples of its use, with the aim of contributing to increase the digital skills of citizens in general.

Both documents are very useful, since they offer everyone in general, and teachers in particular, a way to perceive their level of digital competence and, from there, to find which changes need to be made so that they can develop at that level.

One of the most interesting aspects in this instrument is that it is not limited to assessing the degree of use per se of digital technologies, but integrates it into a broad strategy of interaction between the student's learning, evaluation and evolution. However, more than just listing a set of competences, this instrument provides users with a report that, based on the answers given, makes suggestions for improving the practices teachers already have. (figure 2). The authors of the European project understand that, for now, it is normal for most teachers to fit into levels B1 and B2 (respectively, integrator and expert), also expecting that there will be no results at the extreme levels, i. e., A1 and C1 (Benali, Kaddouri \& Azzimani, 2018). 
Figure 2

DigCompEdu progression model

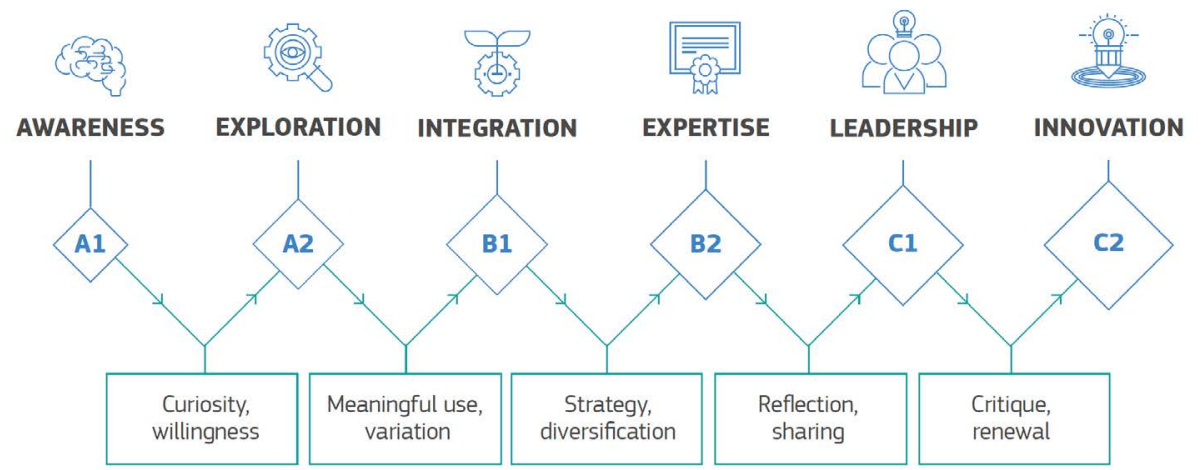

Source: Redecker \& Punie (2017, p. 29)

The instrument presents 22 items, each related to a specific competence identified in the document DigCompEdu (Redecker \& Punie, 2017), and is divided by three dimensions and six subdimensions (table 2).

Table 2

Dimensions, subdimensions and competences in DigCompEdu

\begin{tabular}{|c|c|c|}
\hline Dimensions & Subdimensions & Competences \\
\hline \multirow{4}{*}{$\begin{array}{l}\text { Educator's professional } \\
\text { competences }\end{array}$} & \multirow{4}{*}{ Professional engagement } & 1- Organizational communication \\
\hline & & 2- Professional collaboration \\
\hline & & 3- Reflective practice \\
\hline & & 4- Digital CPD \\
\hline \multirow{13}{*}{$\begin{array}{l}\text { Educators' pedagogic } \\
\text { competences }\end{array}$} & \multirow{3}{*}{ Digital resources } & 5- Selecting \\
\hline & & 6- Creating \& modifying \\
\hline & & 7- Managing, protecting, sharing \\
\hline & \multirow{4}{*}{ Teaching and learning } & 8- Teaching \\
\hline & & 9- Guidance \\
\hline & & 10- Collaborative learning \\
\hline & & 11- Self-regulated learning \\
\hline & \multirow{3}{*}{ Assessment } & 12- Assessment Strategies \\
\hline & & 13- Analysing evidence \\
\hline & & 14- Feedback \& planning \\
\hline & \multirow{3}{*}{ Empowering learners } & 15- Accessibility \& inclusion \\
\hline & & 16- Differentiation \& personalization \\
\hline & & 17- Actively engaging learners \\
\hline \multirow{5}{*}{ Learners' competences } & \multirow{5}{*}{$\begin{array}{l}\text { Facilitating learners' digital } \\
\text { competence }\end{array}$} & 18- Information \& media literacy \\
\hline & & 19- Communication \\
\hline & & 20- Content creation \\
\hline & & 21- Responsible use \\
\hline & & 22- Problem solving \\
\hline
\end{tabular}




\section{Reliability of the Instrument}

Different tests were performed to test the internal consistency of the instrument. The corrected item-total correlation and the squared multiple correlation tests (table 3) allowed to understand that the instrument has the necessary internal consistency, even though it presents some weaker values that suggest that some of the instrument's items could be refined.

Table 3

Analysis of the instrument's internal consistency by item*

\begin{tabular}{|c|c|c|c|c|}
\hline \multirow[t]{2}{*}{ Subdimension } & \multicolumn{2}{|c|}{ Item } & \multirow{2}{*}{ 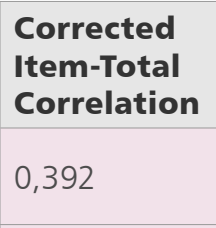 } & \multirow{2}{*}{$\begin{array}{l}\text { Squared } \\
\text { Multiple } \\
\text { Correlation } \\
0,180\end{array}$} \\
\hline & 1 & $\begin{array}{l}\text { I use different digital communication channels for } \\
\text { different purposes. }\end{array}$ & & \\
\hline \multirow[t]{3}{*}{ D1 } & 2 & $\begin{array}{l}\text { I use digital technologies to work together with } \\
\text { colleagues inside and outside my school. }\end{array}$ & 0,303 & 0,105 \\
\hline & 3 & $\begin{array}{l}\text { I continuously reflect on how I can improve my use of } \\
\text { digital technologies in teaching and learning. }\end{array}$ & 0,415 & 0,179 \\
\hline & 4 & I participate in online training opportunities. & 0,342 & 0,119 \\
\hline \multirow{3}{*}{ D2 } & 5 & $\begin{array}{l}\text { I use different internet sites and search strategies to } \\
\text { find and select digital resources. }\end{array}$ & 0,402 & 0,178 \\
\hline & 6 & $\begin{array}{l}\text { I create my own digital resources and modify existing } \\
\text { ones to adapt them to my needs. }\end{array}$ & 0,522 & 0,298 \\
\hline & 7 & I effectively protect sensitive content. & 0,340 & 0,137 \\
\hline \multirow{4}{*}{ D3 } & 8 & $\begin{array}{l}\text { I carefully consider how, when and why to use digital } \\
\text { technologies in class, to ensure that they are used } \\
\text { with added value. }\end{array}$ & 0,530 & 0,323 \\
\hline & 9 & $\begin{array}{l}\text { I monitor learners' behaviour and engagement in the } \\
\text { collaborative digital environments I use. }\end{array}$ & 0,522 & 0,306 \\
\hline & 10 & $\begin{array}{l}\text { When my students work in groups or teams, } \\
\text { they use digital technologies to generate and } \\
\text { document evidence. }\end{array}$ & 0,491 & 0,315 \\
\hline & 11 & $\begin{array}{l}\text { I use digital technologies to allow learners to monitor } \\
\text { their learning themselves. }\end{array}$ & 0,336 & 0,166 \\
\hline \multirow{3}{*}{ D4 } & 12 & $\begin{array}{l}\text { I use digital assessment formats to monitor } \\
\text { student progress. }\end{array}$ & 0,468 & 0,301 \\
\hline & 13 & $\begin{array}{l}\text { I reflect on the digital and non-digital evidence } \\
\text { I have on learners' behaviour and progress to } \\
\text { better understand individual problems. }\end{array}$ & 0,127 & 0,018 \\
\hline & 14 & $\begin{array}{l}\text { I use digital technologies to provide effective } \\
\text { feedback and help students understand their } \\
\text { learning needs. }\end{array}$ & 0,452 & 0,295 \\
\hline \multirow{3}{*}{ D5 } & 15 & $\begin{array}{l}\text { When I create digital assignments for learners } \\
\text { I consider and address problems they may have } \\
\text { with the digital format. }\end{array}$ & 0,512 & 0,276 \\
\hline & 16 & $\begin{array}{l}\text { I use digital technologies to provide my students } \\
\text { personalised learning opportunities. }\end{array}$ & 0,581 & 0,338 \\
\hline & 17 & $\begin{array}{l}\text { I use digital technologies to more actively } \\
\text { involve learners. }\end{array}$ & 0,464 & 0,226 \\
\hline
\end{tabular}




\begin{tabular}{l|l|l|l|l}
\hline \multirow{2}{*}{18} & $\begin{array}{l}\text { I teach learners how to check if information is reliable } \\
\text { and to identify fake news. }\end{array}$ & 0,629 & 0,414 \\
\cline { 2 - 5 } & 19 & $\begin{array}{l}\text { I set up assignments which require learners to use } \\
\text { digital means to communicate with each other or } \\
\text { with an outside audience. }\end{array}$ & 0,589 & 0,403 \\
\cline { 2 - 5 } 20 & $\begin{array}{l}\text { I set up assignments which require learners to } \\
\text { create digital content. }\end{array}$ & 0,517 & 0,284 \\
\cline { 2 - 5 } 21 & $\begin{array}{l}\text { I teach learners how to behave safely and } \\
\text { responsibly online. }\end{array}$ & 0,588 & 0,377 \\
\cline { 2 - 5 } & 22 & $\begin{array}{l}\text { I encourage learners to use digital technologies } \\
\text { creatively to solve concrete problems. }\end{array}$ & 0,654 & 0,445 \\
\hline
\end{tabular}

* In this table, items signaled in red have a very low internal consistency (bellow .399); items in yellow have low internal consistency (bellow 499) and items with no color have good or very good internal consistency (above .500).

Source: own source

The same instrument, in its original English version, has already been applied to a group of 160 Moroccan teachers (Benali et al., 2018), and its internal consistency analysis $(a=.91)$ showed similar results to this research, which has an alpha of .90 and, therefore, a high internal consistency.

\section{Data Analysis}

The methodology followed is based on a quantitative approach. For each of the 22 competences of the instrument, a statement (item) is presented and the participants must select one of the five options that best characterises their position in relation to the same statement, on a Likert scale, ranging from "no, I do not do this at all", to "yes, I do this comprehensively".

For example:

\section{Area [Subdimension] 1}

Item 1-I use a variety of different digital communication channels for a variety of purposes.

1- Not at all: I do not use digital communication channels.

2- Not really: I use the same digital communication channel for everything.

3- Sometimes I vary communication channels.

4- Yes, I respect the preferences of students and parents.

5- Yes, I strategically choose between different digital alternatives. 
For each of the items, the same levels of points are assigned, ranging from 0 , for the first answer, to 4 points, for the last one. In this sense, the total of the instrument is 88 points, divided by six levels of competence:
A1-Newcomer, below 20 points
A2-Explorer, between 20 and 33 points
B1-Integrator, between 34 and 49 points
B2-Expert, between 50 and 65 points
C1-Leader, between 66 and 80 points
C2-Pioneer, more than 80 points

Therefore, those who mostly choose the first option are thus considered "newcomers". The truly pioneers will have to answer the highest option in at least two thirds of the 22 items to achieve the highest level of competence.

\section{Results of Research}

The results of the different dimensions show an average that places the participating teachers at the B1 - Integrator- level, given that the average obtained is 49 points (of a maximum of 88), but very close to level B2 (which starts at 50 points). According to the authors of the original questionnaire, this level indicates that respondents have the following characteristics:

Integrator: You experiment with digital technologies in a variety of contexts and for a range of purposes, integrating them into many of your practices. You creatively use them to enhance diverse aspects of your professional engagement. You are eager to expand your repertoire of practices. You are, however, still working on understanding which tools work best in which situations and on fitting digital technologies to pedagogic strategies and methods. You just need some more time for experimentation and reflection, complemented by collaborative encouragement and knowledge exchange to become Experts (B2). ${ }^{1}$

As can be seen in figure 3, Dimensions two - Educators' pedagogic competences - and three - Learners' competences - are the ones that present lower values. Among them, subdimensions - Assessment - and Empowering learners - (from Dimension two) stand out, as well as the subdimension —Facilitating learners' digital competence — in Dimension three.

1 This information is presented in the feedback given by DigCompEdu Checkin after online participation. 
The analysis of each of the 22 competences, shows that of the three with the lowest values, two are part of the dimension related to Educators' pedagogical competences, namely to the subdimension Teaching and learning, Self-regulated learning competence, and subdimension Assessment, in particular, Feedback and planning competence. The Communication competence, included in the Dimension Learners' competences, Subdimension Facilitating learners' digital competence, is the third of this set.

Figure 3

Average and Standard Deviation

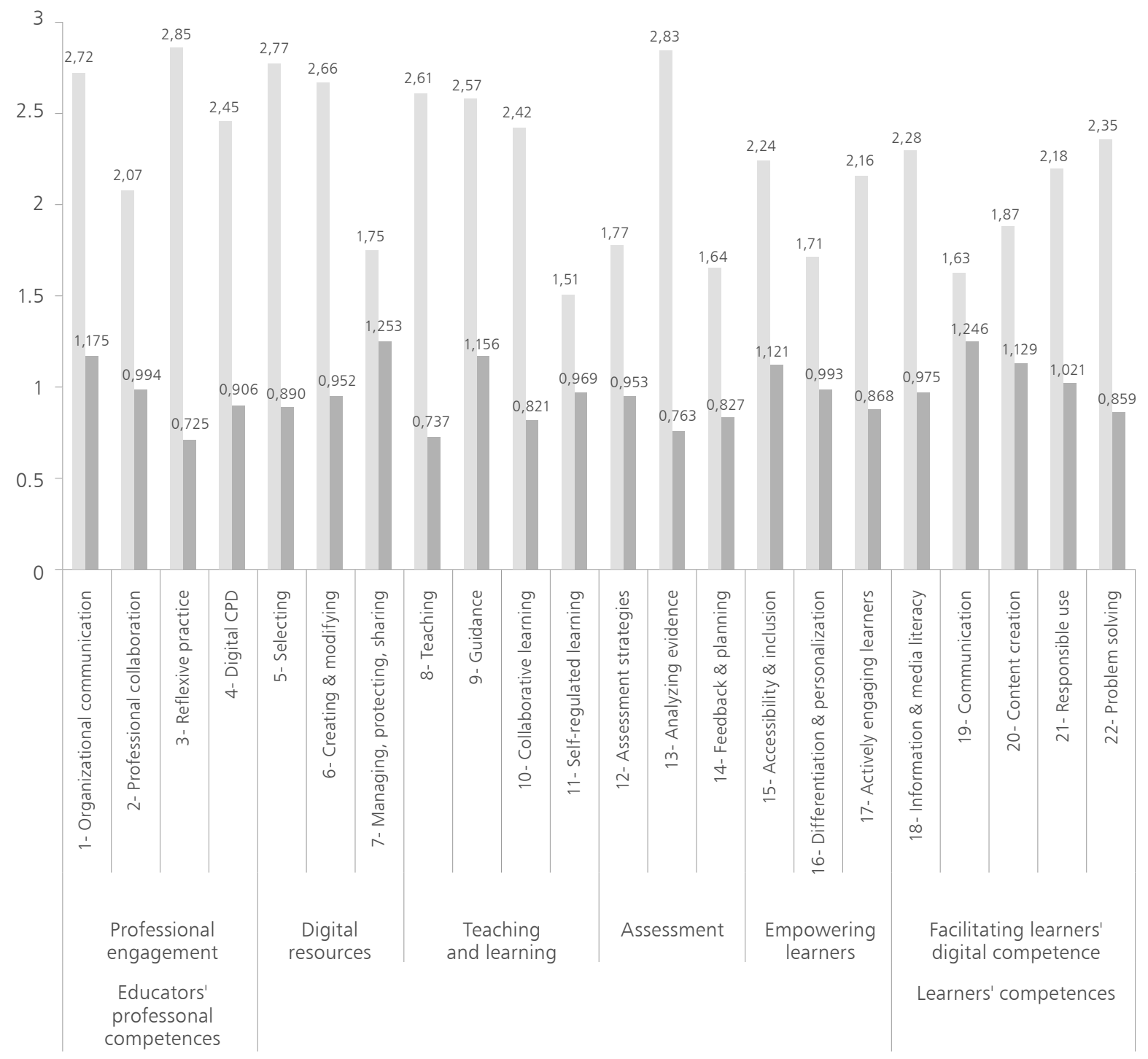

- Average $\quad$ Standard Deviation 
These three competences correspond to the following items of the instrument:

11-I use digital technologies to allow learners to monitor their learning themselves;

14-I use digital technologies to provide effective feedback;

19-I set up assignments which require learners to use digital means to communicate and collaborate with each other or with an outside audience.

Of the 22 competences, the three that present higher average values (above 2,75 points) are numbers 3, 5 and 13, respectively, on Reflective practice (dimension 1 -Educators' professional competences-, subdimension Professional Engagement), Selecting material (dimension 2 -Educators' pedagogic competences-, subdimension Digital resources) and Analysing evidence (dimension 2 -Educators' pedagogic competences-, subdimension Assessment). They correspond to the following items:

3-I actively develop my digital teaching skills;

5-I use different Internet sites and search strategies to find and select a range of different digital resources;

13-I analyse all data available to me to timely identify students' who need additional support.

\section{Discussion}

Until now, there aren't many studies that not only assess high school teachers' digital competences but also suggest ways to improve results obtained. With the questionnaire prepared by the EU Science Hub it became possible to identify in detail what digital competences seem to present more difficulties for teachers.

The results reflect that teachers still have a long way to go until they reach the desired digital fluency, level C2 — Pioneer-, defined as the maximum level by the instrument used —DigCompEdu—, in accordance with the assessment criteria already presented.

Indeed, overall, the digital competence level of the teachers involved in this research is moderate, level B1 _ Integrator-, and the dimensions with the lowest values are Educators' pedagogic competences and Learners' competences. According to what has been defined for this level, teachers "need a little more time for experimentation and reflection, complemented by collaborative support and knowledge sharing, to become Expert". 
The results also highlight, within the first of these dimensions, subdimensions four - Assessment - and five _Empowering learners - , and in the second one, subdimension six -Facilitating learners' digital competence - as the ones where teachers need to invest a bit more.

Also, the dimension in which teachers perceive they have more competences is Dimension one - Educators' professional competences-, in particular in terms of organisational communication and reflexive practice, seeing that this is where the highest results are noted, close to level B2 - Expert- which does not mean that they don't have to invest more in training to achieve the next level, that of Leader (C1) or Pioneer (C2).

All these are directly related to the definition presented for level B1, Integrator, that is, professionals who use digital technologies, are willing to use and reflect on this -in line with items 3, 5 and 13- but who still need to understand how to adapt the different digital tools to their objectives, their strategies and methodologies -items 11, 14 and 19 refer precisely to an articulated use with the students so that they take ownership of these same tools when constructing their knowledge.

The data show that teachers perceive that they have competences in the first dimension - Educators' professional competences - since the highest results are obtained in this dimension, approaching B2 level $-E x$ pert-, although it does not mean that they don't have to invest in more training, also in this dimension, in order to reach the next levels, Leader (C1) or Pioneer (C2).

\section{Conclusions}

As technologies in the digital era are fast developing, education institutions must find mechanisms to develop innovative and sustainable ecosystems and learning environments in which new students can live as the true digital nomads they are, hiperconnected and moving around in a streamlined and hybrid way in face-to-face and virtual spaces.

Accordingly, the topic of digital fluency has become an inescapable issue in all discourses on educational technologies, with much discussion going on whether these resources really do help create these emerging ecosystems and learning environments. However, the question that keeps cropping up not only concerns the use of technologies and the existence of a digital literacy, but, deeper than that, has to do with understanding how this technology can be used to achieve the desired goals, in other words, what must be done to be a true "digitally fluent" user. Both teacher and students alike must try to "learn to work" in these digital environments and 
"learn to use" different tools, with teachers having added responsibilities in this process as they are the architects of these environments.

Therefore, and according to this research's results and to the pilotstudy conducted by Benali et al. (2018), it can be concluded that in addition to the appropriate psychometric features of the instrument, the digital competence level is also identical in the Portuguese and Moroccan cohort of teachers.

Analyzing in more detail the twenty-two competences of the instrument, it's clear that the competences that are most articulated with an adaptation to the different needs of its students are the ones that reflect greater difficulties to be achieved. When these refer to feedback, to selfregulated learning, to the adaptation of learning, that is, to practical work according to the needs of the students, greater difficulties arise in the adaptation to the digital context. On the other hand, competences related to a teacher's individual work, to a reflexive practice and planning, are the ones that collet, on average, the higher results.

Similar to other studies in this area (Claro et al., 2018; Hatlevik, 2016; Instefjord \& Munthe, 2017; Ramírez-Montoya, Menab \& RodríguezArroyo, 2017), these findings show the need for teachers to increase their digital competence levels through specific training, especially as regards the pedagogical use of technology. This training should be practical and experimental in nature, so that teachers feel confident about using digital technologies not only in collaboration with their peers, but especially with their students.

It is, therefore, necessary to initiate educational processes aimed at improving and developing the professional quality of teachers, using training models consistent with the pedagogical dynamics of the social web, such as the TPACK model (Koehler \& Mishra, 2008). This model is not only a frame of reference of the knowledge that teachers are required to have when teaching using technology, but also a training model that could benefit the definition of a "new" didactics for digital teaching, based on the scientific and pedagogical knowledge of technology. By identifying the type of knowledge needed to integrate technology in teaching, this model can be quite an effective response to address the digital competence shortcomings identified in this research.

Finally, although these resources produced by the EU Science Hub are very relevant as tools to assess the teachers' level of digital competence, it is nevertheless necessary to conduct more such studies to validate the constructed instruments. In fact, the instrument used, translated to Portuguese with the authors' permission, has proved to be trustworthy instrument with psychometric features, so its use in future studies to be developed in this 
area would be interesting. In fact, besides the good indicators of validity, overall the measures applied are characterised by what is believed to be good or adequate reliability, assuming, therefore, that they consistently assess the variables they are meant to measure, thus being an instrument capable of contributing to the assessment of teachers' digital competence level. Despite these validity indicators, they need to be applied to larger samples, so that both dimensions with the lowest values can improve.

Nevertheless, the small dimension of the sample is a limitation to this study, and it is necessary to apply the instrument in all Portuguese territory, in order to obtain a much more representative sample of Portuguese teachers' digital competences. The findings will allow the preparation of differentiated training, in digital competences, depending on difficulties found in the instrument's different dimensions.

It can indeed be claimed that today's education requires that the pedagogical process is seen in a different way. However, change should not be seen from a technological viewpoint only, but also in terms of mentality and of pedagogical practice. This implies a cultural change, as it calls for a review of the roles of teachers and students, and of the relation between them. Teaching and learning in this digital society using digital technologies is, without a doubt, an attractive challenge, yet at the same time very demanding. This is why it is so important to invest in training models, such as the TPACK, that identify the nature of knowledge required for integrating technology in teaching, allowing teachers to reach the desired digital fluency.

\section{About the authors}

Sara Dias-Trindade is PhD in History, didactics. Assistant teacher at the University of Coimbra, Portugal. Researcher in the areas of Education, Digital Technologies, Digital Fluency and Cinema in Education.

José António Moreira is PhD in Education. Teacher at Open University, Portugal. Researcher in the areas of Education, Digital Technologies, Digital Fluency and Cinema in Education.

\section{References}

Beetham, H. \& Sharpe, R. (2007). Rethinking Pedagogy for a Digital Age: Designing and Delivering e-Learning. New York: Routledge.

Benali, M., Kaddouri, M. \& Azzimani, T. (2018). Digital competence of Moroccan teachers of English. International Journal of Education and Development Using Information and Communication Technology (IJEDICT), 14(2), 99-120.

Briggs, C. \& Makice, K. (2011). Digital Fluency: Building Success in the Digital Age. Galway: SociaLens. 
Carvalho, A. A. \& Pessoa, T. (2012). Políticas educativas TIC en Portugal. Campus Virtuales, 1(1), 93-104.

Claro, M. et al. (2018). Teaching in a Digital Environment (TIDE): Defining and measuring teachers' capacity to develop students' digital information and communication skills. Computers \& Education, 121, 162-174.

Cox, S. (2008). A Conceptual Analysis of Technological Pedagogical Content Knowledge (doctoral dissertation). Brigham Young University: Provo, UT.

European Commission. (2012). Rethinking Education: Investing in Skills for Better Socio-Economic Outcomes. COM(2012) 669 final. Retrieved from ec.europa. eu/newsroom/dae/document.cfm?doc_id=2877

EU Science Hub. (2019). Learning and Skills for the Digital Era. Retrieved from https://ec.europa.eu/jrc/en/research-topic/learning-and-skills

EUSurvey. (n. d.). DigCompEdu Check-In. Retrieved from https://ec.europa.eu/ eusurvey/runner/DigCompEducheckin

Figueiredo, A. D. (2016). Por uma escola com futuro... Para além do digital (For a school with a future... beyond digital). Nova Ágor-Revista, 5, 19-21.

Floridi, L. (Ed.). (2015). The Onlife Manifesto: Being Human in a Hyperconnected Era. s. I.: Springer Open. Retrieved from https://link.springer.com/content/ pdf/10.1007\%2F978-3-319-04093-6.pdf\%3E

From, J. (2017). Pedagogical digital competence: Between values, knowledge and skills. Higher Education Studies, 7(2), 43-50.

Generalitat de Catalunya. (2018). Teachers' Digital Competence in Catalonia. Retrieved from http://ensenyament.gencat.cat/web/.content/home/departa ment/publicacions/monografies/competencia-digital-docent/Competenciadigital_angles_web.pdf

Hatlevik, O. E. (2016). Examining the relationship between teachers' self-efficacy, their digital competence, strategies to evaluate information, and use of ICT at school. Scandinavian Journal of Educational Research, 61(5), 555-567.

Ilomäki, L., Paavola, S., Lakkala, M. \& Kantosalo, A. (2016). Digital competence: An emergent boundary concept for policy and educational research. Educ Inf Technol, 21, 655-679. doi: 10.1007/s10639-014-9346-4

Instefjord, E. J. \& Munthe, E. (2017). Educating digitally competent teachers: A study of integration of professional digital competence in teacher education. Teaching and Teacher Education, 67, 37-45.

Koehler, M. J. \& Mishra, P. (2008). Introducing TPCK. In M. C Herring, M. J. Koehler \& P. Mishra (Eds.), The Handbook of Technological Pedagogical Content Knowledge (TPCK) for Educators (pp. 3-29). New York, NY: Routledge.

McKnight, K., O’Malley, K., Ruzic, R., Horsley, M. K., Franey, J. J. \& Bassett, K. (2016). Teaching in a digital age: How educators use technology to improve student learning. Journal of Research on Technology in Education, 48(3), 194-211. doi: 10.1080/15391523.2016.1175856

Miller, C. \& Bartlett, J. (2012). 'Digital fluency': Towards young people's critical use of the internet. Journal of Information Literacy, 6(2), 35-55.

Mishra, P. \& Koehler, M. L. (2006). Technological pedagogical content knowledge: A framework for teacher knowledge. Teachers College Record, 6, 1017-1054. 
National Research Council (NRC). (1999). Being Fluent with Information Technology. Washington, DC: National Academy Press.

Ozan, O. \& Kesim, M. (2013). Rethinking scaffolding in mobile connectivist learning environments. In Z. Berge \& L. Muilenburg (Eds.), Handbook of Mobile Education (pp. 166-175). New York: Routledge.

Pettersson, F. (2018). On the issues of digital competence in educational contexts: A review of literature. Education and Information Technologies, 23(3), 1005-1021.

Ramírez-Montoya, M. S., Menab, J. \& Rodríguez-Arroyo, J. A. (2017). In-service teachers' self-perceptions of digital competence and OER use as determined by a XMOOC training course. Computers in Human Behaviour, 77, 356-364.

Redecker, C. \& Punie, Y. (2017). European Framework for the Digital Competence of Educators (DigCompEdu). Luxembourg: Publications Office of the European Union. Retrieved from https://ec.europa.eu/jrc/en/publication/ eur-scientific-and-technical-research-reports/european-framework-digitalcompetence-educators-digcompedu

Schlemmer, E. \& Backes, L. (2015). Learning in metaverses: Co-existing in Real Virtuality. Hershey: IGI Global.

The National Institute of Educational Technologies and Teacher Training (INTEF). (2017). Common Digital Competence Framework for Teachers. Retrieved from https://aprende.intef.es/sites/default/files/2018-05/2017_1024-Com mon-Digital-Competence-Framework-For-Teachers.pdf

Trindade, S. D. \& Moreira, J. A. (2017). A Emergência do Mobile Learning e os Novos Desafios Formativos para a Docência em Rede [Mobile learning emergency and the new formative challenges for networked learning]. In P. Torres (Org.), Redes e mídias sociais [Networks and social media] (pp. 41-57). Curitiba: APPRIS.

Trindade, S. D. \& Moreira, J. A. (2018). Ecologia de aprendizagem [Digital ecology]. In D. Mill (Org.), Dicionário crítico de educação e tecnologias e educação a distância [Dictionary of education and technology and distance learning] (pp. 192-193). Campinas: Papirus.

United Nations Educational, Scientific and Cultural Organization (UNESCO). (2011). Media and Information Literacy Curriculum for Teachers. Paris: UNESCO. Retrieved from https://unesdoc.unesco.org/ark:/48223/pf0000192971

Van Laar, E., Van Deursen, J. A. M., Van Dijk, J. A. G. M. \& Hann, J. (2017). The relation between 21 st-century skills and digital skills: A systematic literature review. Computers in Human Behaviour, 72, 577-588.

Wang, E., Myers, M. \& Sundaram, D. (2012). Digital natives and digital immigrants: Towards a model of digital fluency. In ECIS 2012 Proceedings, 39. Retrieved from http://aisel.aisnet.org/ecis2012/39

White, G. K. (2013). Digital Fluency: Skills Necessary for Learning in the Digital Age. Melbourne: ACER. 